\title{
Pelatihan Kebersihan dan Tata Letak Rumah Tinggal (homestay) di Desa Wisata Cikolelet
}

\author{
Lyly Soemarni Lioe ${ }^{1}$, Kezia Elsty ${ }^{2}$, Renata Taat ${ }^{3}$, Gibran Galeb ${ }^{4}$, \\ Fauriyah Irfah $^{5}$, Siti Rahmawati ${ }^{6}$, Donnie Wijaya ${ }^{7}$ \\ Program Studi Pariwisata Universitas Pradita
}

lyly.soemarni@pradita.ac.id, kezia.elsty@pradita.ac.id, renata.taat@pradita.ac.id.

\begin{abstract}
Abstrak
Pembangunan desa wisata perlu dilakukan dengan komitmen antar pemangku kepentingan dan masyarakat lokal secara berkelanjutan dan merata bagi semua warga desa. Sumber daya manusia merupakan hal yang perlu diperhatikan karena menjadi roda penggerak aktivitas desa wisata yang membawa kontribusi ekonomi masyarakat lokal. Sumber daya manusia di desa wisata Cikolelet yang masih minim dan pengetahuan mereka mengenai pariwisata dan pengelolaannya masih terbatas, peningkatan akan pendidikan dan pengetahuan masyarakat lokal harus ditingkatkan untuk mendukung tumbuhnya sektor pariwisata di Desa Wisata Cikolelet. Kegiatan pengabdian kepada masyarakat ini dilaksanakan sebagai salah satu upaya meningkatkan kapasitas pelaku wisata rumah tinggal di desa Wisata Cikolelet dengan pembekalan untuk mengelola rumah tinggal (homestay) menjadi tempat penginapan yang bersih dan nyaman bagi wisatawan. Kegiatan ini berlangsung selama 1 hari penuh diikuti oleh pengelola/ pemilik rumah tinggal (homestay) dari 8 rumah tinggal yang tersedia. Metode yang digunakan berupa paparan SOP kebersihan dan tata letak ruang tinggal serta kelengkapannya, kemudian dilanjutkan dengan bekunjung ke lokasi rumah tinggal dan melakukan evaluasi antar peserta. Manfaat dari kegiatan ini memberikan gambaran terkait kebersihan, peletakkan dan kelengkapan standar yang dibutuhkan untuk menjadikan rumah tinggal nyaman bagi wisatawan dan memberikan saran praktis bagi pemilik rumah tinggal untuk menciptakan suasana nyaman dan aman.
\end{abstract}

Kata Kunci: kebersihan, tata letak, homestay, desa wisata

\section{PENDAHULUAN}

Pembangunan daerah tertinggal maupun desa di Indonesia dapat terlaksana dengan adanya komitmen antara pemerintah dan masyrakat. Dengan adanya nota kesepahaman antara Kementerian Pariwisata dengan Kementerian Desa, Pembangunan Daerah Tertinggal dan Transmigrasi tentang Pengembangan Desa Wisata yang tertuang dalam nomor 10/M-DPDTT/KB/XII/2016 menyatakan kedua belah pihak melakukan sinergi tugas dan fungsi dalam rangka meningkatkan penyelenggaraan pengembangan desa wisata sebagai destinasi pariwisata berkualitas, berdaya saing dan berkelanjutan. Salah satu bentuk wisata unggulan daerah yang saat ini sangat popular dikembangkan adalah desa wisata. Desa wisata telah menjadi komponen yang semakin populer dari strategi pembangunan di banyak daerah terbelakang, dengan pengembangan terhadap potensi pariwisata daerah dalam rangka meningkatkan ekonomi lokal dan taraf hidup masyarakat lokal (Muganda et al., 2010).

Pengembangan desa wisata sebagai salah satu alternatif dari peningkatan wisata yang sudah

$$
\text { Pendidikan }
$$


ada menjadi wisata yang kompleks dan diminati, penambahan jenis wisata ini dapat menghasilkan produk pariwisata mengalami peningkatan setiap tahun, salah satu provinsi yang permintaan produk pariwisatanya semakin meningkat adalah provinsi Banten. Kunjungan wisatawan seperti daerah provinsi Banten mengalami kenaikan yang signifikan seperti terlihat dari data BPS (2019) pada tahun 2017 sejumlah 9.551 .703 menjadi 13.275.125 ditahun 2018. Tren peningkatan kunjungan wisatawan tersebut dipandang beberapa pemangku kepentingan pariwisata daerah sebagai peluang pasar yang sangat menjanjikan bagi pengembangan pariwisata.

Peningkatan kunjungan wisatawan juga tidak terlepas dengan daya tarik wisata yang ditawarkan di desa wisata Cikolelet. Desa wisata Cikolelet sendiri memiliki destinasi alam yang indah seperti Gunung Pilar, Puncak Cibaja, Air Terjun Curug Kembar dan Curug Lawang. Pembangunan sarana dan pra-sarana pada destinasi wisata alam pun sudah mulai dilakukan dengan adanya permainan seperti outbound, flying fox dan tempat-tempat untuk wisatawan ber-selfie dengan latar belakang pemandangan yang indah. Pembangunan pun dilakukan pada bidang lain seperti jaringan listrik, sarana jalan akses wisata, pembinaan ekonomi kreatif masyarakat, penataan landskap, dan sebagainya dilakukan untuk memajukan desa Wisata Cikolelet (Fauzi, 2018).

Jumlah pengunjung ke desa wisata Cikolelet sebanyak 800 orang setiap bulannya pada tahun 2019 (Suprina, dkk., 2019). Pengunjung ada yang merupakan wisatawan luar daerah atau masyarakat sekitar yang ingin berwisata di desa wisata Cikolelet. Seiring dengan penambahan jumlah wisatawan, jumlah tempat menginap tentu harus memadai untuk para wisatawan. Rumah-rumah penduduk desa wisata Cikolelet pun dijadikan sebagai tempat menginap wisatawan. Pemanfaatan rumah penduduk desa wisata Cikolelet sebagai tempat menginap menjadi hal yang baik bagi penduduk maupun wisatwan karena melalui hal ini penduduk mendapatkan kontribusi ekonomi dan wisatawan mendapat pengalaman untuk tinggal di desa alih-alih tinggal di hotel besar. Homestay adalah penginapan lokal (Sulistyawatu \& Suarka, 2017) yang merupakan rumah tinggal yang sebagian kamarnya disewakan kepada tamu dalam jangka waktu tertentu dan hidup berdampingan masyarakat dan memiliki pengalaman menjadi penduduk di suatu tempat tertentu.

Dalam rangka menyambut wisatawan yang menginap, maka rumah tinggal (homestay) harus terstandarisasi dengan benar untuk menunjang kenyamanan wisatawan saat menginap. Kebersihan dan tata letak pada rumah tinggal (homestay) menjadi hal dasar dan penting untuk diterapkan pada semua rumah tinggal (homestay) terutama yang berada di desa wisata Cikolelet. Dalam memahami standar kebersihan dan tata letak pada rumah tinggal (homestay), pelatihan pada para pemilik rumah tinggal (homestay) perlu dilakukan supaya menambah pengetahuan mereka dalam mengelola rumah tinggal (homestay) mereka dengan lebih baik.

Peserta yang merupakan penduduk yang rumahnya dijadikan rumah tinggal (homestay) mengikuti semua tahapan dala pelatihan sampai selesai dan diharapkan peserta memahami dan melaksanakan standarisasi kebersihan dan tata letak rumah tinggal (homestay) secara konsisten di masa yang akan datang. Dalam pelatihan ini juga diberikan pemahaman mengenai bagaimana menjaga kenyamanan dan privasi wisatawan saat menginap di rumah tinggal (homestay) milik penduduk. Dengan demikian diharapkan wisatawan dapat kembali berkunjung ke desa wisata Cikolelet karena merasa puas dengan pelayanan rumah tinggal (homestay) yang diberikan.

\section{METODE}

Bentuk kegiatan pengabdian kepada masyarakat yang dilakukan berjudul "Pelatihan kebersihan dan tata letak rumah tinggal (homestay) di Desa Wisata Cikolelet" pada hari Rabu, 22 Januari 2020, pukul 09.30-16.30. Kegiatan diawali dengan pembukaan di Pendopo rumah Kepala Desa wisata Cikolelet, kemudian dilanjutkan dengan memperkenalkan kelompok pelaku homestay dan pengurus pokdarwis. Kegiatan pelatihan diawali dengan pemaparan materi standar kebersihan dan tata letak ruang kamar yang kemudian dilanjutkan dengan mendatangi rumah tinggal (homestay) milik warga yang mengikuti pelatihan dan melakukan evaluasi rumah tinggal (homestay) dengan menggunakan form evaluasi yang sudah disediakan

$$
\text { Pendidikan }
$$


disertakan poin-poin standar untuk menilai sebuah rumah tinggal (homestay) berdasarkan kebersihan pekarangan, ruang tamu, ruang makan, kamar mandi, dan kamar tidur serta tata letak dari perabot penunjang rumah tinggal (homestay). Selain itu pengetahuan dan masukkan terhadap beberapa hal terkait pengelolaan rumah tinggal (homestay) seperti tidak perlu menyediakan amenities kamar seperti sabun, shampoo, sikat gigi, sisir, dsb sehingga tidak dijadikan komponen biaya saat menentukan harga sewa rumah tinggal layanan menginap melainkan pemilik dapat menjual amenities sesuai kebutuhan dengan harga yang terjangkau.

Materi Pelatihan Kebersihan dan Tata Letak Rumah Tinggal (Homestay) di Desa Wisata Cikolelet.

1. Homestay adalah usaha penyediaan akomodasi berupa bangunan rumah tinggal yang dihuni oeh masyarakat dan dimanfaatkan untuk disewakan dengan memberikan kesempatan kepada wisatawan untuk berinteraksi dalam kehidupan sehari-hari dari pemiliknya

2. Fasilitas utama : Bangunan rumah tinggal yang layak dan dihuni oleh pemiliknya serta sebagian kamarnya dimanfaatkan untuk disewakan kepada wisatawan

3. Alasan mengapa tamu tinggal di homestay?

a. Tinggal di homestay serasa seperti tinggal di rumah keluarga sendiri

b. Harga yang relative terjangkau

c. Minimnya jumlah hotel di Kawasan wisata

d. Bisa menampung banyak orang (lebih fleksibel daripada hotel)

4. Apa saja syarat yang dibutuhkan untuk mengubah rumah Bapak/Ibu agar menjadi Homestay yang layak dan digemari wisatawan

a. Rumah (dapur, kamar tidur, toilet)

1) Menjaga kebersihan seluruh isi rumah tanpa terkecuali (termasuk daerah private dari pemilik homestay)

2) Menjaga privasi dari tamu (tidak seenaknya masuk ke dalam kamar untuk mengambil barang)

3) Memberikan waktu kepada tamu untuk melakukan kegiatan yang bersifat pribadi (tidak selalu harus Bersama tamu)

4) Memberikan rasa nyaman dan aman kepada tamu yang menginap
5) Memasak atau mempersiapkan manakan dengan layak (boleh sederhana tetapi harus tetap menjaga higienitas dan kebersihan)

b. Lingkungan sekitar

1) Lingkungan sekitar bebas sampah.

2) Membasmi perkembangbiakan nyamuk (terutama Nyamuk Aedes) seperti drains tersumbat, dibuang kaleng, dll

3) Menghidupkan lagi system keamanan desa seperti siskamling agar tamu merasa aman saat sedang menginap

5. Penataan Rumah yang ideal untuk dijadikan Homestay

a. Taman/pekarangan rumah

1) Jika ada rumput, dirawat agar selalu rapih

2) Sampah atau daun sebaiknya disapu setiap hari

3) Hindari membakarsampah di area rumah dan sekitarnya

b. Pendopo dan Ruang Tamu

1) Selalu dalam keadaan bersih

2) Biasakan untuk menempatkan alas kaki (sepatu dan sandal) di satu sudut (diberikan Rak sepatu)

3) Ruang tamu jangan dalam keadaan gelap/redup, cara lain selain menyalakan lampu adalah dengan membuka jendela dan gorden.

4) Tersedia tempat sampah atau asbak

c. Dapur

1) Selalu dalam keadaan bersih dan bebas dari sampah (agar tidak ada kecoa dan tikus)

2) Tidak ada air yang menggenang

3) Diperlukan fentilasi yang memadai agar asap dari masakan tidak langsung menuju ruang tamu atau kamar dari tamu

4) Tersedia air bersih

5) Tersedia saluran pembuangan yang memadai

d. Ruang makan

1) Tersedia makan dan minum

2) Sirkulasi udara dan pencahayaan yang cukup

3) Selalu tersedia tissue/lap makan

4) Terjaga jebersihannya dan tidak berbau 
e. Kamar Tamu

1) Diharapkan tidak ada barang pribadi dari pemilik rumah yang diletakan di kamar tamu (untuk menghindari terganggunya privasi dari tamu tersebut)

2) Memiliki sirkulasi udara yang cukup

3) Penerangan yang memadai dengan pencahayaan lampu atau cahaya matahari pada siang hari (agar hemat listrik)

4) Jendela harus memiliki gorden atau tirai

5) Sebaiknya memakai warna yang cerah untuk dinding kamar tamu

6) Pengaturan furniture dan barang yang tertata rapi

7) Terdapat kunci di pintu yang memungkinkan tamu untuk mengunci kamar

8) Perlengkapan yang dibutuhkan untuk kamar tidur
a) Tempat tidur/Kasur
b) Bantal
c) Sprei (boleh bermotif atau berwarna cerah)
d) Selimut (tergantung kebutuhan. Jika ruman berada di dataran rendah, sebaiknya menyediakan selimut yang tipis saja)
e) Meja biasa atau meja rias dengan kaca
f) Lemari tempat penyimpanan pakaian dan barang berharga dari tamu
g) Handuk (sebaiknya handuk berwarna netral seperti abu-abu atau coklat dan tidak bermotif/polos)
h) Tempat sampah kecil
i) Jika daerah tersebut berada di dataran rendah, bisa diberikan kipas angin (optional)

f. Kamar Mandi

1) Sebaiknya kamar mandi menyatu dengan bangunan utama

2) Memiliki sirkulasi udara yang cukup

3) Tersedia air bersih yang cukup dan penerangan yang cukup

4) Lantai tidak licin dan tidak berlumut (termasuk dinding kamar mandi)

5) Kamar mandi tidak bau
6) Terdapat tempat untuk sabun, shampoo, dll

7) Terdapat gantungan untuk handuk, dan pakaian.

6. Menjaga kebersihan dan kerapihan Homestay

a. Tempat sampah harus dikosongkan setiap pagi

b. Sapu dan pel lantai setiap hari

c. Ganti sprei dan handuk tamu setiap 3 hari sekali

d. Bersihkan kamar mandi

e. Bersihkan langit-langit rumah settidaknya sebulan sekali (untuk menghilangkan sarang laba-laba

7. Extra charge (untuk menekan harga kamar homestay

a. Jika pemilik homestay tidak memasukan anggaran untuk amenities, bisa menjual amenities kepada tamu (tetapi dengan harga yang sepantasnya). Pemilik homestay bisa membuat counter kecil untuk menjual amenities atau peralatan mandi yang mungkin akan dibutuhkan oleh tamu.

b. Untuk makan tamu, harga yang diberikan kepada tamu bisa sudah include dengan makanan (misalnya $2 \mathrm{x}$ sehari atau $3 \mathrm{x}$ sehari), atau tidak termasuk dan dapat menanyakan mengenai makanan pada saat tamu check in.

8. Biasakan diri untuk tersenyum, yang harus diingat adalah janga lupa tersenyum, memberi salam, menyapa, sopan, dan santun. 3 kata yang sebaiknya dihindari : Tidak bisa, tidak tahu, dan habis

9. Setelah tamu check-in, berikan sedikit penjelasan tentang peraturan yang berlaku di homestay tersebut. Peraturan bisa berbeda antara satu homestay dengan homestay yang lain. Contoh dari peraturan:

a. Menjaga suasana yang tenang dan tidak menggangu lingkungan khususnya setelah jam 10 malam.

b. Ikut menjaga kebersihan rumah 


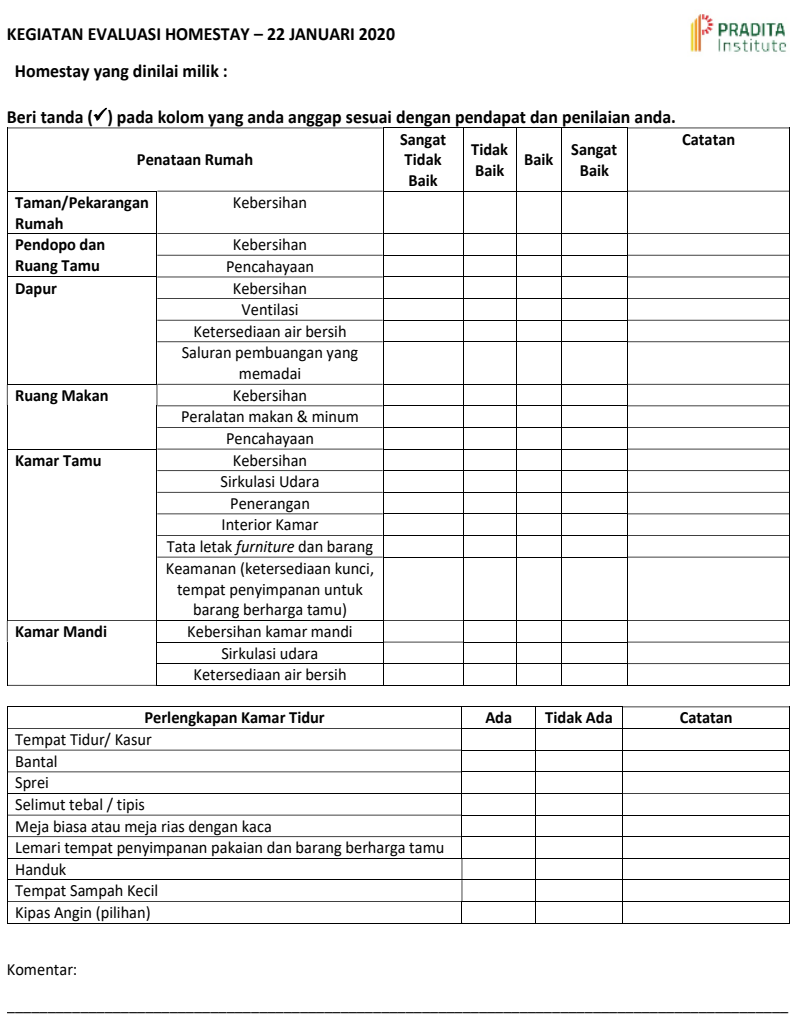

Gambar 1. Check list penilaian mandiri

\section{HASIL DAN PEMBAHASAN}

Perlatihan kebersihan dan tata letak (homestay) di desa wisata Cikolelet memberikan pengetahuan mengenai standar kebersihan dan tata letak rumah tinggal (homestay) yang disesuaikan dengan kapasitas pemilik rumah tinggal (homestay). Pemenuhan kelengkapan perabot atau perangkat tambahan lain bukan menjadi tujuan dari pelatihan ini, namun dalam mengelola rumah tinggal (homestay) yang baik harus dimulai dari memperhatikan kebersihan dan tata letak yang sangat mungkin untuk dilakukan oleh pemilik rumah tinggal (homestay) tanpa harus mengeluarkan biaya tambahan untuk membeli perabot atau keperluan tambahan lain. Kegiatan pelatihan ini dilakukan kepada delapan [8] pemilik rumah tinggal yang rumahnya dijadikan homestay. Pelatihan ini memberikan gambaran umum dalam menciptakan rumah tinggal (homestay) yang bersih, nyaman, tetap menjaga privasi wisatawan yang akan menginap dan diskusi mengenai skema harga yang terjangkau untuk dapat ditawarkan kepada para calon wisatawan.

Kegiatan dilanjutkan dengan mengunjungi dua [2] rumah tinggal (homestay) dengan nama White Rose dan Kantil. Peserta saling melakukan evaluasi terhadap dua rumah tinggal (homestay) ini dengan menggunakan form evaluasi yang disediakan. Peserta saling memberikan masukkan terhadap apa yang mereka lihat dalam konteks kebersihan dan tata letak. Pada kunjungan ini didapat bahwa ada rumah tinggal (homestay) yang kebersihan kamar mandinya belum terpenuhi dan lantai menuju kamar mandi basah dan lembap. Pemanfaatan kapasitas dan apa yang tersedia pada masing-masing rumah tinggal (homestay) dan alam sekitar dapat dimaksimalkan daripada harus berpikir untuk menambah perabot seperti pendingin ruangan atau televisi.

Peserta masih banyak yang bertanya mengenai harga yang harus ditetapkan untuk menjual layanan penginapan pada rumah tinggal (homestay) mereka. Kebanyakan peserta menetapkan harga per orang yang terlalu tinggi dan kurang sebanding dengan fasilitas yang didapat sehingga penetapan harga yang terjangkau sesuai dengan fasilitias yang ditawarkan perlu dilakukan ke depannya. Selain itu pemilik masih ragu untuk menentukan menu makanan yang harus mereka sajikan pada rumah tinggal (homestay) mereka untuk wisatawan yang menginap di sana. Hal yang mungkin dilakukan adalah dengan saling bekerja sama dan memberi manfaat kepada tetangga di sekitar rumah tinggal (homestay) yang sudah menjual menu makanan mereka untuk dapat juga dijual di rumah tinggal (homestay) sehingga pemilik tidak perlu merepotkan diri untuk memikirkan dan menyiapkan menu yang juga belum tentu akan dibeli oleh wisatawan yang menginap. 
Tabel 1. Susunan Acara

\begin{tabular}{|c|c|c|}
\hline $\begin{array}{l}\text { WAKTU } \\
\text { WIB) }\end{array}$ & KEGIATAN & KETERANGAN \\
\hline 66.00-06.30 & $\begin{array}{l}\text { Persiapan menuju } \\
\text { Lokasi Desa wisata } \\
\text { Cikolelet }\end{array}$ & $\begin{array}{l}\text { Mengecek kesiapan peralatan dan perlengkapan yang akan } \\
\text { digunakan, serta memulai loading kedalam bus }\end{array}$ \\
\hline 6.30-09.00 & $\begin{array}{l}\text { Perjalanan menuju } \\
\text { Desa wisata } \\
\text { Cikolelet }\end{array}$ & $\begin{array}{l}\text { Perjalanan menuju desa wisata Cikolelet selama } 2.5 \text { jam di } \\
\text { langsung ke lokasi acara, }\end{array}$ \\
\hline j9.30-10.00 & $\begin{array}{l}\text { Pembukaan oleh } \\
\text { Kepala desa dan } \\
\text { staff desa Cikolelet } \\
\text { Doa }\end{array}$ & $\begin{array}{l}\text { Acara dilakukan di teras kediaman kepala desa } \\
\text { Set up bangku dan meja oleh pokdarwis } \\
\text { Bahan pelatihan, Banner spanduk, Registrasi, ballpoint, Kert } \\
\text { Dokumentasi. }\end{array}$ \\
\hline $10.00-12.30$ & $\begin{array}{l}\text { Pelatihan } \\
\text { kebersihan dan tata } \\
\text { letak rumah tinggal } \\
\text { (homestay) }\end{array}$ & $\begin{array}{l}\text { Paparan dimulai dengan membagikan lembar petunjuk, disku } \\
\text { dengan pelaku homestay sebanyak } 08 \text { rumah homestay. Papar } \\
\text { disampaikan oleh instruktur dari Pradita Institute dan diban } \\
\text { oleh mahasiswa. Kemudian pembahasan lembar check list ya } \\
\text { digunakan untuk evaluasi homestay, kemudian di prakt ikk } \\
\text { bersama dengan peserta kegiatan. }\end{array}$ \\
\hline $12.30-13.30$ & ISOMA & \\
\hline $13.30-15.00$ & $\begin{array}{l}\text { Kunjungan ke } \\
\text { rumah tinggal } \\
\text { (homestay }\end{array}$ & $\begin{array}{l}\text { Instruktur dan peserta melakukan kunjungan ke rumah tingga } \\
\text { (homestay) milik warga (White Rose dan Kantil) milik warga } \\
\text { dan saling melakukan evaluasi dan memberi masukkan. }\end{array}$ \\
\hline $15.00-16.00$ & Evaluasi Kegiatan & $\begin{array}{l}\text { Pengisian check list dan diskusi tentang. } \\
\text { Setelah kunjungan ke hosmetay maka dilakukan evaluasi } \\
\text { kondisi homestay dan saran perbaikan yang dapat dilakukan } \\
\text { oleh pemilik Homestay dan evaluai mengenai program pelatił } \\
\text { dan manfaatnya bagi peserta. }\end{array}$ \\
\hline $16.00-16.30$ & Penutupan & $\begin{array}{l}\text { Pengisian kues ioner dan foto bersama untuk dokumentasi } \\
\text { kegiatan. Dan penutupan kegiatan PkM. }\end{array}$ \\
\hline $16.30-19.30$ & Perjalanan ke & \\
\hline
\end{tabular}

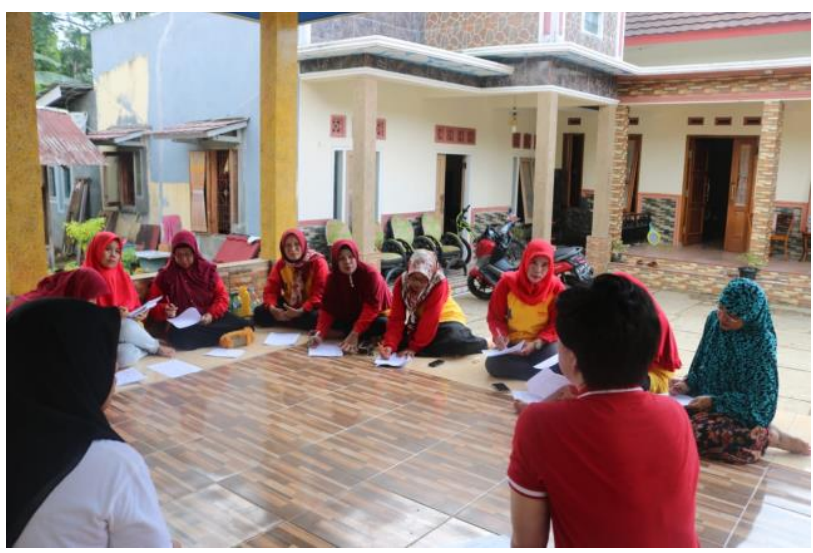

Gambar 2. Pemaparan dan diskusi

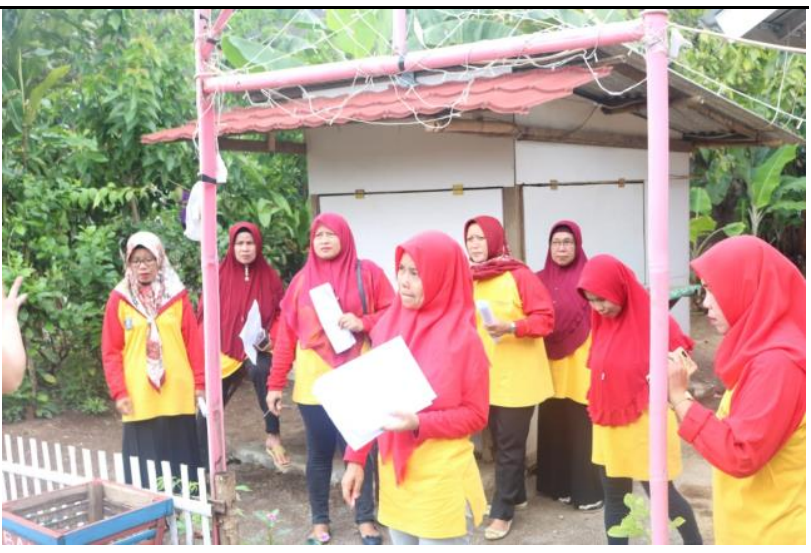

Gambar 3. Meninjauan lingkungan Homestay

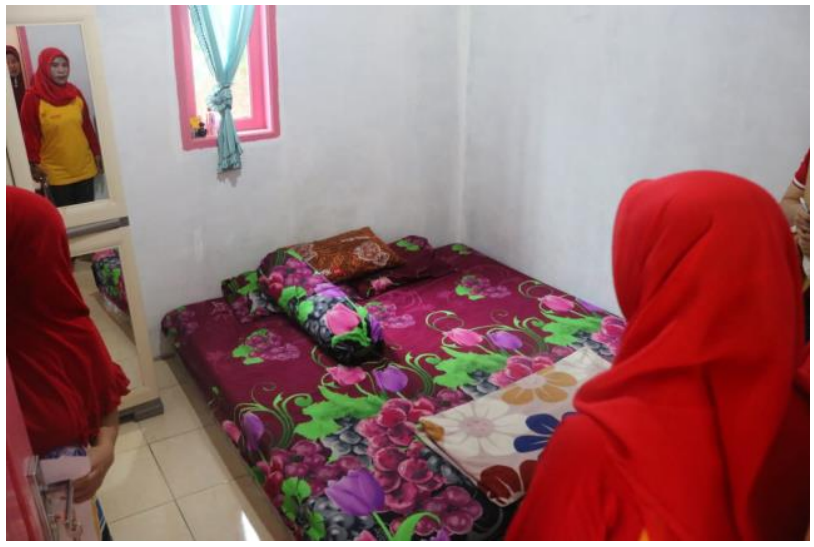

Gambar 4. Asesment Mandiri Ruang Tidur

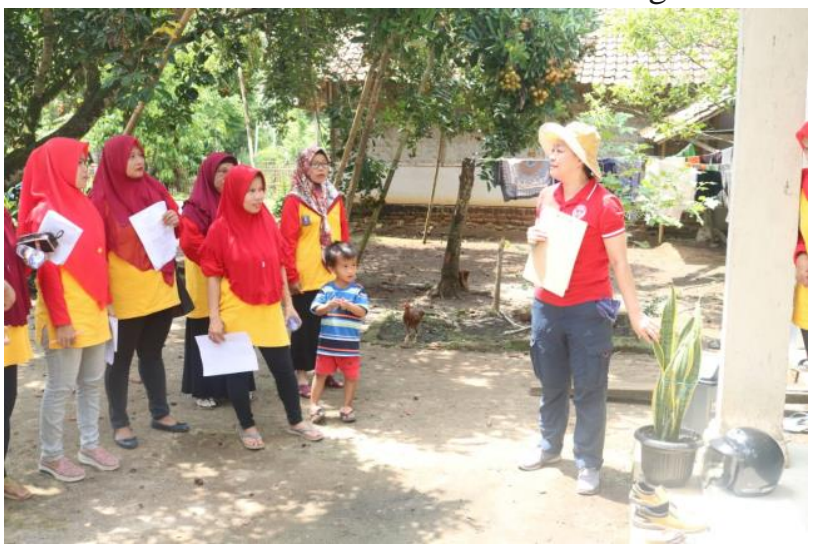

Gambar 5. Meninjau Halaman Homestay 


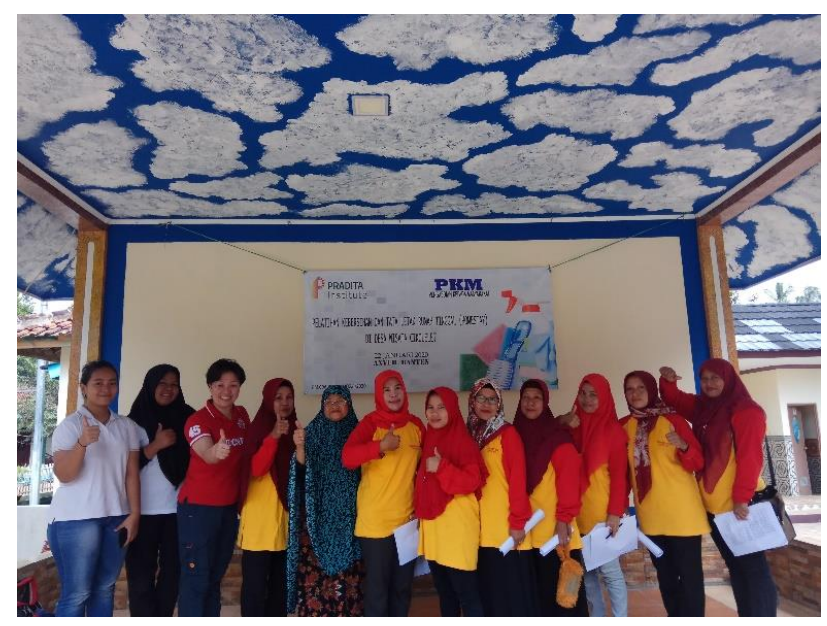

Gambar 6. Peserta PkM, mahasiswa dan instruktur

\section{SIMPULAN}

Dari hasil pengamatan yang telah dilakukan dan umpan balik yang diterima dapat disimpulkan bahwa;

1. Peserta yang mengikuti pelatihan ini mendapatkan pengetahuan dan keterampilan cara menjaga kebersihan dan mengatur tata letak sesuai standar yang ditentukan dengan memperhatikan kapasitas masing-masing pemilik rumah tinggal (homestay).

2. Peserta bersedia mempraktikan cara melakukan kebersihan dan mengatur tata letak pada rumah tinggal (homestay) mereka.

3. Peserta bersedia melakukan perbaikan yang mendasar untuk mencapai standar kebersihan dan menata kembali ruang tidur.

4. Peserta bersemangat memperhatikan lingkungan sekitar rumah tinggal dengan melakukan penghijauan.

5. Peserta dapat melakukan evaluasi mandiri antar pemilik rumah tinggal (homestay) sehingga dapat saling memberikan masukkan untuk kemajuan bersama.

6. Peserta dapat memanfaatkan warga sekitar untuk menawarkan menu lokal sehingga tamu mendapatkan kesempatan untuk merasakan masakan khas setempat.

Manfaat dari kegiatan ini tidak hanya diterima oleh peserta pelatihan tapi juga bermanfaat bagi program studi Pariwisata sebagai upaya pelaksanaan Tri Dharma Perguruan Tinggi, turut serta membantu program kerja pemerintah untuk meningkatkan pariwisata pedesaan dan keterlibatan dalam kegiatan ini menumbuhkan nilai kebersamaan dengan masyarakat dan solidaritas khususnya bagi mahasiswa.

\section{REFERENSI}

BPS., (2019). Jumlah Kunjungan Wisatawan Nusantara, 2015 - 2018. https://www. bps.go.id/dynamictable/2019/09/24/1645/jumlahkunjungan-wisatawan-nusantara-2015---2018.html/, diakses pada 24 Januari 2020.

Fauzi, Moch Prima. (2018). Desa Wisata Cikolelet, Sajikan Keindahan Alam Kabupaten Serang.https://travel.detik.com/travel-news/d4315650/desa-wisata-cikolelet-sajikan-keindahanalam-kabupaten-serang, diakses pada 7 Februari 2020.

Kementerian Pariwisata, (2019). Nota Kesepahaman antara Kementerian pariwisata dan Kementerian Desa, Pembangunan Daerah Tertinggal dan Transmigrasi tentang Pengembangan Desa Wisata, https://www.kemenpar.go.id/categories/kesepakatan -bersama?\&page $=4$, diakses pada 7 Februari 2020.

Muganda, M., Sahli, M. and Smith, K. (2010). Tourism's contribution to poverty alleviation: a community perspective from Tanzania. Development Southern Africa. Vol 27. No 5, pp.629-646. DOI: $10.10800376835 X .2010 .522826$.

Sulistyawati, Agung Sri dan Suarka, Fanny Maharani. (2017). Strategi Pengembangan Penginapan Lokal (Homestay) Untuk Mendukung Desa Wisata Tista, Kec. Kerambitan, Kab. Tabanan. Seminar Nasional Sains dan Teknologi. 
